DR DAVID ROBIE is associate editor of Pacific Journalism Review.

\section{Just like the} pandemic, action on climate is urgent

Climate Aotearoa: What's happening and what we can do about it, edited by Helen Clark. Auckland: Allen \& Unwin, 2021. 327 pages. ISBN 9781988547633

W HEN the publication of Climate Aotearoa was heralded by Radio New Zealand in April 2021 it was featured alongside a striking image and a quote from the collection editor, former prime minister Helen Clark. The illustration by Vinay Ranchhod was a dazzling red lobster in a boiling pot.

I would liken [the challenge of climate change] to being the lobster in the pot and the pot starts to heat, and by the time it's realised it's being cooked, it's too late to change. Its fate is sealed.

That's in essence the message: you've got time to act, the window is closing. And if you don't, you're going to get over those tipping points from which there's no return. ('Time for action', 2021)

The question is whether this message of urgency is being heeded. Less than two months later, New Zealand's final 419-page Climate Change Commission report was unveiled in Parliament

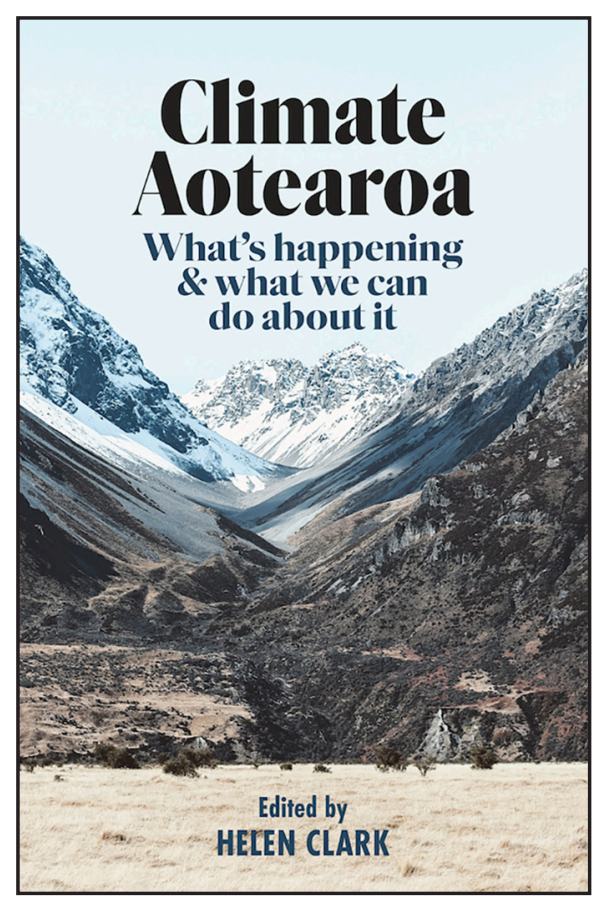

to mixed reactions. The report called on the government to get tough on the way New Zealanders live, move and work to help keep global warming below $1.5 \mathrm{degC}$; it ruled out new or used petrol and diesel-powered vehicle imported or assembled by 2035 .

As technocrats and policy makers considered details on what the report recommended that New Zealand should do, environmental and social justice commentator Simon Wilson wrote that there was a fundamental question to answer: 'how do we create a hearts and minds movement for change, particularly on transport?

For this volume, Clark has brought together a dozen contributors - a balanced range of analysts, disability and social advocates, engineers, journalists, researchers and scientists. It is divided 
into three parts: The Science, The Issues and The Solutions.

In her four-page introduction, Clark notes how this book is being published while the COVID-19 pandemic and its repercussions continue to play out around the world, including New Zealand (albeit with a muted community infection profile).

The difference in nature between these two global crises is striking, she writes. For example, warnings of pandemic risk over the years have attracted 'far less publicity than those of the impact of climate change'. Yet the difference is far more stunning.

When COVID-19 struck, however, its impact was rapid, dramatic and highly visible with far-reaching effects across human health, economies and societies. In the case of climate change, its impacts unfold over time as a slower onset disaster; if not addressed decisively, they will be far-reaching across the full spectrum of biological and non-biological systems. (Clark, p. 10)

In addition, Clark argues that, while effective measures for addressing the impact of COVID-19 have emerged quickly - such as physical distancing, hygiene, mask-wearing, testing and tracing systems, quarantine, treatment and now vaccination, there is no parallel set of measures with immediate and dramatic impact for climate change mitigation-all necessary measures that take time to implement and gain traction.

The sheer scale of 'social and economic carnage wrought by COVID-19' has forced governments to act, some more effectively than others. Although there has been 'staunch advocacy' by many over the climate crisis, there has not been the same sense of urgency.

In this book, the longer-term concerns are set out in perspective, with Haylee Koroi emphasising that the indigenous Māori have been dealing with 'the dynamics of the environment for centuries' while scientist Dr Jim Sallinger reminds New Zealand that apparently 'small' differences in average temperature have a 'huge effect on the environment and the lives of plants and animals'.

In discussing The Science, Dr Rob Bell, Matt McGlone, and Simon Thrush and Andrew Jeffs provide comprehensive updates on what the research says about the impact of sea level rise, the effects of climate change on biodiversity and aquatic environments.

This sets the scene for The Issues section with Rhys Jones and Kera Sherwood-O'Regan canvassing the health impacts of climate change while activists Jason Boberg and Sophie Handford approach the challenges of the wider community from the perspective of people with disabilities and young people respectively.

Then comes The Solutions section which, interestingly for this journal, is written entirely by three journalists, perhaps unusually so given that media is too often more associated with providing problems rather than solutions.

Jamie Morton, the remarkably perceptive science journalist with The New 
Zealand Herald, argues that individuals can definitely make a difference. He also stresses that news media and scientists ought to avoid doomsday narratives and focus on positive messages. He also says that perhaps most New Zealanders want the government to be bold, 'even if the rest of the world doesn't seem to bother'. (p. 247)

Business journalist Ron Oram, of Newsroom, argues that New Zealand needs to draw on its 'proven record of innovation' in agriculture and species protection to contribute to restoring ecosystems to enable sustainably feeding a forecast global population of 10 billion people by 2050 .

We can transform our land use, agriculture and food production so that they benefit our indigenous species and ecosystems. We can turn one cause of the climate crisis into a soluton. (p. 266)

Environmental journalist Adelia Hallett, who edits Carbon News, has faith in nature as the only 'technology' proven to be able to actually increase the amount of carbon dioxide being taken out of the atmosphere on the scale needed. She argues for many radical ideas of working with nature, such as a 'blue carbon' approach over mangroves and wetlands. However, she also calls for a fundamental change in our attitude.

The COVID-19 pandemic has shown us just how fast 'normal' can be swept away ... As with the COVID-19 pandemic, change is not optional. We cannot continue life as usual. If we try to party up like there's no tomorrow, we will have to cope with the changes to the physical environment that are probably beyond our imaginations right now. (p. 303)

However, as Helen Clark notes in her introduction, what is reassuring about this book is that it demonstrates that New Zealand possesses a community of scientists, journalists and activists who are passionate and well-informed about climate change. More importantly, they are actively seeking solutions to the crisis.

\section{References}

Clark, H. (2021, April 21). 'Time for action'-Helen Clark urges climate change response.

Interview with RNZ Checkpoint. Retrieved on June 13, 2021, from https:// www.rnz.co.nz/national/programmes/ checkpoint/audio/2018792528/timefor-action-helen-clark-urges-climatechange-response

Climate Change Commission (2021, June). Ināia tonu nei: a low emissions future for

Aotearoa. Retrieved on 12 June, 2021, from https://ccc-production-media. s3.ap-southeast-2.amazonaws.com/ public/Inaia-tonu-nei-a-low-emissionsfuture-for-Aotearoa/Inaia-tonu-nei-alow-emissions-future-for-Aotearoa.pdf

Todd, K. (2021, June 9). Climate Commission report falls short on dairy industry emissions - critics. RNZ News. Retrieved on June 12, 2021, from https:// www.rnz.co.nz/news/national/444378/ climate-commission-report-falls-shorton-dairy-industry-emissions-critics 